\title{
Thouinidium cyrilli-nelsonii (Sapindaceae), a new tree species from El Salvador
}

\begin{abstract}
José L. Linares ${ }^{1}$
Abstract. A new tree species, Thouinidium cyrilli-nelsonii from El Salvador is described and illustrated, and its taxonomic affinities are discussed.
\end{abstract}

Key words: Inventory of trees, new species.

Resumen. Se describe e ilustra Thouinidium cyrilli-nelsonii J. Linares una nueva especie de árbol de El Salvador y se discuten sus posibles afinidades taxonómicas.

Palabras clave: Inventario de árboles, especie nueva.

\section{Introduction}

While conducting a preliminary inventory of trees of El Salvador, a new species of Thouinidium was found. A detailed study of specimens of all other published species of the genus, from the herbaria of the Jardín Botánico La Laguna (LAGU), the National Herbarium of México (MEXU), the Herbarium Paul C. Standley at Escuela Agrícola Panamericana (EAP), the Herbarium of the Universidad de El Salvador (ITIC), and the Herbarium of the Museo de Historia Natural de El Salvador (MUHNES) revealed that this is a new species, which is herein described:

Thouinidium cyrilli-nelsonii J. Linares, sp. nov. Figura 1.

Type. EL SALVADOR. SANTA ANA: Municipio Metapán, cerro de Los Cántaros, \pm km 16 al NE de Metapán, Parque Nacional Montecristo, elev. 1400 m, 1 March 2002, Víctor Manuel Martínez s. n. (Holotype, MEXU).

Arbor 5-10 m; ramuli florales puberuli ferruginei, valde sympodiales; folia alterna, circinata, paripinnata; foliola 6-12, 2.6-8.5 × 0.8-2.2 cm, praecipue oblonga, dentata tantum dimidio distali. Flores non vidi. Fructus schizocarpium, 3 mericarpiis samaroideis, 7-8 $\times 2 \mathrm{~cm}$, oblique oblongis.

Trees 5-10 m high; branchlets puberulent, ferrugineous; flowering branchlets conspicuously sympodial, floral shoots borne on the buds near the apex; leaves alternate, spirally arranged, 8-15 cm long, petiole 2.2-3.2 cm long, subterete, minutely pubescent; rachis 3.5-7.6 cm long, striated, minutely pubescent; leaflets 6-12, 2.6-8.5 cm long, 0.8-2.2 cm wide, oblong, sometimes elliptic, midrib minutely pubescent on both surfaces, blades glabrous on the upper side and minutely pubescent on the lower side, then glabrescent, the base cuneate to acute, petiolule 1-3 $\mathrm{mm}$ long, minutely pubescent, margin entire on the proximal half and serrate with 4-10 teeth, the apex acute to obtuse. Inflorescences 8-10 cm long, 3-6 cm wide (in fruit). Flowers not seen, but probably pedicellate. Fruit a trimerous schizocarp, indehiscent, glabrous, splitting into 3 samara-like mericarps 7-8 cm long, $2 \mathrm{~cm}$ wide at the widest part, with welldeveloped wings, obliquely oblong in shape, slightly trapeziform, the apex obtuse, conspicuously veined. One seed per mericarp. Seed 1.5-1.7 long, 1.1 wide and 2-3 mm thick, brown, obovate, hilum close to the base of the seed.

Etymology. The specific epithet honors the Honduran botanist Cyril Hardy Nelson Sutherland (Cirilo Nelson) for his outstanding contributions to the knowledge of Central American plants.

Distribution, habitat and phenology. This species is only known from one collection from the middle

1 email: linaresj_98@yahoo.com 
slopes of Montecristo National Park, in pine-oak forest at $1700 \mathrm{~m}$. It flowers probably from May to June, and fruits from January to March.

Discussion. The genus Thouinidium comprises six species, distributed from Mexico through Central America, as well as in the Antilles. T. decandrum (Bonpl.) Radlk., amply distributed from Mexico to Costa Rica; T. inaequilaterum Alain, endemic to the Dominican Republic; T. insigne (Brandegee) Radlk., endemic to Mexico in the states of Oaxaca and Puebla; T. oblongum Radlk., endemic to Mexico in the states of Queretaro and Hidalgo; T. pinnatum Radlk., endemic to the island of Hispaniola (Dominican Republic and Haiti), and finally, T. cyrilli-nelsonii, known only from the type locality, and therefore, until now, endemic to El Salvador.

Thouinidium cyrilli-nelsonii is another of several interesting plants from the Montecristo area in the northwestern corner of El Salvador. It is outstanding for the size of the fruits, and also for the characteristics of the leaves and branches. This species is very distinctive by having serrate leaflets with the teeth only in the distal half or close to the tip. Another remarkable features of this species is the large size of the fruits which are distinguished easily from $T$. decandrum, the only other species growing in the Montecristo area, and to which is morphologically most closely related. Table 1 summarizes the morphological differences between the two species.

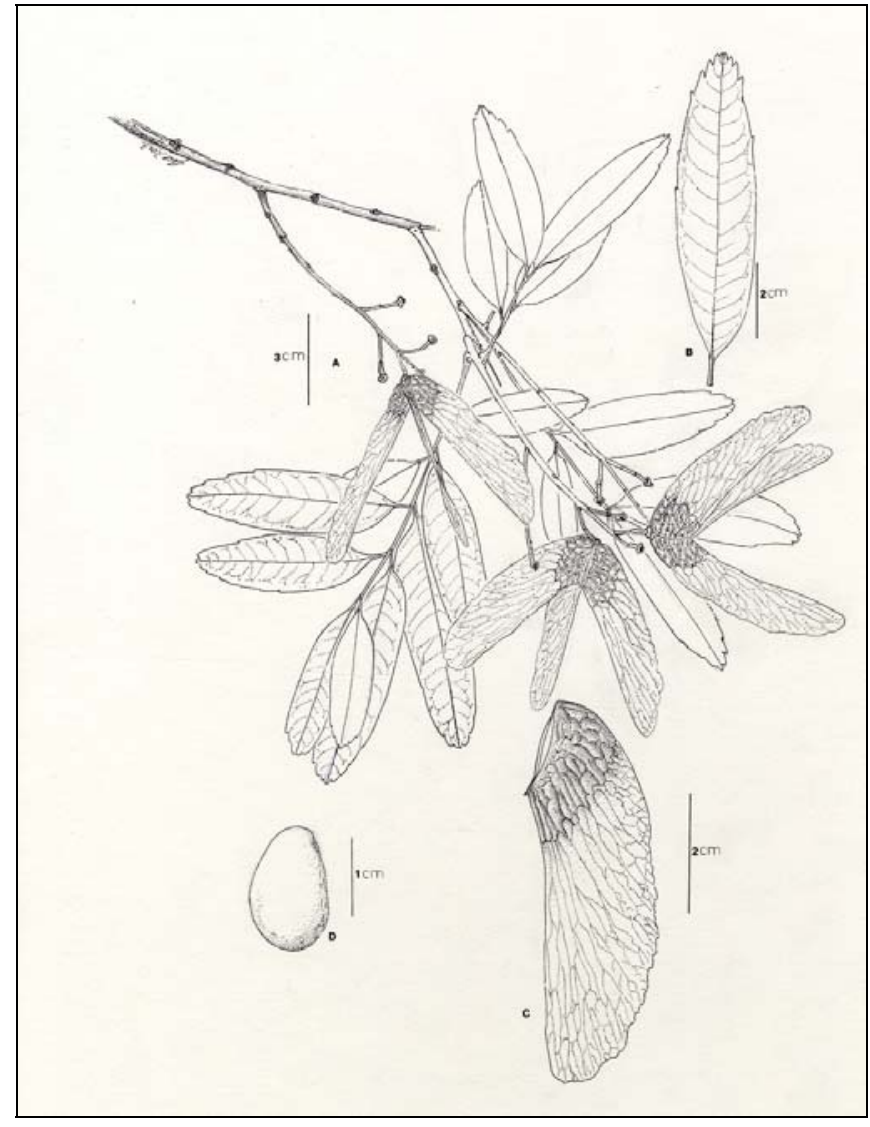

Figure 1. Thouinidium cyrilli-nelsonii. A) Fruiting branch. B) Leaflet. C) Mericarp. D) Seed. All from V.M. Martínez s.n. (MEXU).

Table 1. Morphological differences between Thouinidum decandrum (Bonpl.) Radlk. and Thohinidium cyrillinelsonii J.Linares in El Salvador.

\begin{tabular}{|c|c|c|c|c|c|}
\hline Species & $\begin{array}{c}\text { Number of } \\
\text { leaflets }\end{array}$ & Leaflets & Leaflet margin & Leaflet apex & Fruit size $(\mathrm{cm})$ \\
\hline T. cyrilli-nelsonii & $6-12$ & pedicellate & $\begin{array}{l}\text { serrate toward the } \\
\text { apex }\end{array}$ & rounded to obtuse & $7-8 \times 2.2$ \\
\hline T. decandrum & $4-14$ & sessile & serrate & acute to acuminate & $2.5-3.5 \times 1$ \\
\hline
\end{tabular}

Key to the species of Thouinidium

1. Leaflets 4-14, at least some leaves of the fertile branches with more than 8 leaflets, serrate, either throughout the entire margin or partially so 
2. At least some leaves of the fertile branches with up to 14 leaflets, leaflets serrate throughout the entire margin, glabrous, mericarps 2.5-3.5 × $1 \mathrm{~cm}$.

T. decandrum (Bonpl.) Radlk.

2. Leaves of the fertile branches with 6 leaflets or less, leaflets serrate towards the distal half, minutely pubescent, sometimes glabrescent in age, mericarps 7-8 $\times 2 \mathrm{~cm}$. T. cyrilli-nelsonii J. Linares

1. Leaflets 2-8, no leaf with more than 8 leaflets, margins entire throughout

3. Leaflets glabrous

4. Leaflets 4-6, bases symmetric or nearly so, mericarps of the fruit less than $3.5 \mathrm{~cm}$ long

T. oblongum Radlk.

4. Leaflets 6-8, bases oblique, mericarps of the fruit more than $3.5 \mathrm{~cm}$ long

T. pinnatum Radlk.

3. Leaflets variously pubescent

5. Leaflets densely pubescent, mericarps of the fruit less than $2.2 \mathrm{~cm}$ long, leaflets ovate to broadly ovate, base of the leaflets very oblique. T. inaequilaterum Alain

5. Leaflets velutinous, mericarps of the fruit more than $4 \mathrm{~cm}$ long, leaflets oblong, base of the leaflets almost symmetric T. insigne (Brandegee) Radlk.

List of the accepted species of Thouinidium in this work.

Thouinidium decandrum (Bonpl.) Radlk., Sitzungsber. Math.-Phys. Cl. Königl. Bayer. Akad. Wiss. München 8(3): 284. 1878.

Basionym: Thouinia decandra Bonpl., Pl. Aequinoct. 1: 198-201, t. 56. 1808.

Synonyms: Thouinidium matudae Lundell, Lloydia 4: 53. 1941.

Thouinia riparia Brandegee, Univ. Calif. Publ. Bot. 6(8): 186. 1915.

Thouinidium riparium Radlk., Repert. Spec. Nov. Regni Veg. 17: 363. 1921.

Thouinidium cyrilli-nelsonii J. Linares.

Thouinidium inaequilaterum Alain, Phytologia 22(3): 165. 1971.

Thouinidium inaequilaterum Alain, Phytologia 22(3): 165. 1971.

Thouinidium insigne (Brandegee) Radlk., Repert. Spec. Nov. Regni Veg. 17: 363. 1921.
Basionym: Thouinia insignis Brandegee, Univ. Calif. Publ. Bot. 3(8): 384. 1909.

Synonym: Thouinidium insignis (Brandegee) Standl., Contr. U.S. Natl. Herb. 23(3): 708. 1923. [nomen superfluum non Radlk. 1921].

Thouinidium oblongum Radlk., Sitzungsber. Math.Phys. Cl. Königl. Bayer. Akad. Wiss. München 8: 284. 1878.

Thouinidium pinnatum Radlk., Sitzungsber. Math.Phys. Cl. Königl. Bayer. Akad. Wiss. München 8: 283. 1878.

\section{References}

Reyna, M.L. 1979. Vegetación arbórea del bosque nebuloso de Montecristo. Tesis de Licenciatura. Facultad de Ciencias y Humanidades, Departamento de Biología. Universidad de El Salvador. San Salvador.

Witsberger, D., D. Current y E. Archer. 1982. Árboles del Parque Deininger. Dirección de Publicaciones. Ministerio de Educación. San Salvador, El Salvador.

Recibido para publicación el 10 de julio de 2008. 